\title{
RELATIVE COMPETITIVENESS OF GOOSEGRASS BIOTYPES AND SOYBEAN CROPS $^{1}$
}

\author{
JADER JOB FRANCO ${ }^{2 *}$, DIRCEU AGOSTINETTO ${ }^{2}$, ANA CLAUDIA LANGARO ${ }^{2}$, LAIS TESSARI PERBONI ${ }^{2}$, \\ LEANDRO VARGAS ${ }^{3}$
}

\begin{abstract}
The goosegrass (Eleusine indica (L.) Gaertn) is an annual plant that has a low-level resistance to glyphosate (LLRG), resulting in control failure in genetically modified soybean crops for resistance to this herbicide. Alleles related to resistance may cause changes in the plant biotype, such as inferior competitive ability. Thus, the objective of this work was to evaluated the competitive ability of soybean crops and susceptible and resistant (LLRG) goosegrass biotypes. Replacement series experiments were conducted with soybean crops and goosegrass biotypes. The ratios of soybean to susceptible or resistant (LLRG) goosegrass plants were 100:0, 75:25, 50:50, 25:75 and 0:100, with a total population of 481 plants $\mathrm{m}^{-2}$. The leaf area, plant height and shoot dry weight were evaluated at 40 days after emergence of the soybean crops and weeds. The soybean crop had superior competitive ability to the susceptible and resistant (LLRG) goosegrass biotypes. The soybean crop showed similar competitive ability in both competitions, either with the susceptible or resistant (LLRG) goosegrass biotypes. The intraspecific competition was more harmful to the soybean crop, while the interspecific competition caused greater damage to the goosegrass biotypes competing with the soybean crop.
\end{abstract}

Keywords: Glycine max. Eleusine indica. Competition. Resistance.

\section{COMPETITIVIDADE RELATIVA DE BIÓTIPOS DE CAPIM PÉ-DE-GALINHA COM A CULTURA DA SOJA}

RESUMO - O capim pé-de-galinha (Eleusine indica (L.) Gaertn) é uma planta anual, que apresenta resistência de nível baixo (RNB) ao herbicida glifosato o que acarreta em falhas de controle em lavouras de soja geneticamente modificadas para resistência ao herbicida. Os alelos relacionados com a resistência podem acarretar em custos de adaptação ao biótipo, conferindo menor habilidade competitiva. Diante disso, o objetivo da pesquisa foi comparar a habilidade competitiva da cultura da soja com os biótipos de capim pé-de-galinha suscetível ou com RNB. Para isso, foram conduzidos experimentos em série de substituição entre a cultura da soja e os biótipos de capim pé-de-galinha. As proporções entre plantas de soja e capim pé-de-galinha suscetível ou com RNB foram de 100:0, 75:25, 50:50, 25:75 e 0:100, com população total de 481 plantas $\mathrm{m}^{-2}$. Avaliaram-se a área foliar (AF), estatura de planta (EST) e a massa da matéria seca da parte aérea (MMSPA), aos 40 DAE da cultura da soja e da planta daninha. A cultura da soja tem habilidade competitiva superior aos biótipos de capim pé-de-galinha suscetível ou com RNB. A habilidade competitiva da soja não foi diferencial frente à competição com os biótipos de capim pé-de-galinha suscetível ou com RNB. A competição intraespecífica para a cultura da soja e a competição interespecífica para os biótipos de capim pé-de-galinha, causam maiores danos aos competidores.

Palavras-chave: Glycine max. Eleusine indica. Competição. Resistência.

\footnotetext{
*Corresponding author

${ }^{1}$ Received for publication in $06 / 30 / 2014$; accepted in $10 / 06 / 2016$.

Paper extracted from the masters dissertation of the first author, funded by CAPES.

${ }^{2}$ Department of Plant Protection, Universidade Federal de Pelotas, Pelotas, RS, Brazil; jaderjobfranco@yahoo.com.br, agostinetto.d@gmail.com, namelia.langaro@gmail.com, laliperboni@hotmail.com.

${ }^{3}$ National Center Wheat Research, Empresa Brasileira de Pesquisa Agropecuária, Passo Fundo, RS, Brazil; leandro.vargas@embrapa.br.
} 


\section{INTRODUCTION}

The Brazilian production of soybeans reached more than 95 million $\mathrm{Mg}$ in the 2015/16 crop season and an area of approximately 33 million hectares, representing an increase of $3.6 \%$ in the cultivated area compared with the previous crop season (BRASIL, 2016). Weed management is an essential measure to ensure high yields, especially the chemical control, which is the most practical and efficient method.

The goosegrass [Eleusine indica (L.) Gaertn] is one of the most difficult species to control in Roundup Ready ${ }^{\circledR}$ (RR) crops, especially soybean (ULGUIM et al., 2013). Vargas et al. (2013) identified goosegrass biotypes with low-level resistance to glyphosate (LLRG) using up to $1080 \mathrm{~g}$ of acid equivalent (a.e.) of glyphosate $\mathrm{ha}^{-1}$.

Resistant weed biotypes may have inferior competitive ability, since the development of resistance cause changes in the plant metabolism, defense mechanisms, development or reproduction (VILA-AIUB; NEVE; POWLES, 2009). Thus, the resistance (LLRG) found in goosegrass biotypes may have caused physiological changes, with growth and development losses to this biotype, hindering its competitive ability with crops. The more adapted biotypes are the most competitive and able to increase their relative ratio in the niche over time.

The competition between plant species is a negative interaction in which they compete for one (or more) scarce resource in the environment that is essential for their growth and development, resulting in damage for both species (RADOSEVICH; HOLT; GHERSA, 1997). Competition affects the crop production quantitative and qualitative characteristics, changing its use efficiency of environmental resources such as water, light, $\mathrm{CO}_{2}$ and nutrients (BIANCHI et al., 2006b). The competition in an environment can be intraspecific and interspecific. The interspecific competition is important for phytosanitary management, since it causes yield loss and hinders cultural practices and increases incidence of pests (ALVES et al., 2013).

Moraes et al. (2009) evaluated the interspecific competition between soybean crops and Oryza sativa, and found superior competitive ability for the soybean, with higher relative productivity of leaf area (LA) and shoot dry weight (SDW). However, Agostinetto et al. (2009) found antagonism between soybean and Brachiaria plantaginea, with no competitive dominance of any of the species. Moreover, according to Silva et al. (2014), the soybean has inferior competitive ability to the susceptible or resistant Conyza bonariensis biotypes to the herbicide glyphosate.

The hypothesis of the present work was that resistant (LLRG) goosegrass biotypes have inferior competitive ability to susceptible ones in competition with soybean plants. Thus, the objective of this work was to evaluated the competitive ability of soybean crops and susceptible and resistant (LLRG) goosegrass biotypes.

\section{MATERIAL AND METHODS}

Three experiments were conducted in a greenhouse of the Faculty of Agronomy Eliseu Maciel (UFPel), using soybean seeds of the cultivar Fundacep-59, goosegrass seeds from plants with low -level resistance to glyphosate (LLRG), collected in an area of RR-soybean crop in Boa Vista do Incra, State of Rio Grande do Sul (RS), Brazil (28०56'25"S; $53^{\circ} 24^{\prime} 42.06^{\prime \prime W}$ ) (VARGAS et al., 2013), and goosegrass seeds from susceptible plants, collected in Camaquã RS (3052'25.07"S; 5146'13.86"W). All assays were carried out in 8-liter pots with diameter of $23 \mathrm{~cm}$, filled with a Red-Yellow Argisol (SiBCS), arranged in a completely randomized design.

The first experiment consisted of a sole cultivation of goosegrass to determine the plant population from which the shoot dry weight (SDW) per unit area $\left(\mathrm{g} \mathrm{m}^{-2}\right)$ become independent of the population according to the "constant final production law" (RADOSEVICH; HOLT; GHERSA, 1997). The populations evaluated were 1, $2,4,8,16,32$ and 64 plants per pot (equivalent to $24,48,96,192,385,770$, and 1540 plants $\mathrm{m}^{-2}$, respectively), with four replications.

The SDW of the goosegrass was evaluated at 40 days after emergence (DAE), by weighing their shoots after dried in a forced-air circulation oven at $60^{\circ} \mathrm{C}$ for 72 hours. The data analysis was carried out using the reciprocal production to determine the plant population in which the SDW became constant, which occurred to a population of 32 plants per pot (data not shown). The constant production of SDW of the soybean crop occurred to a population of eight plants per pot (MORAES et al., 2009). Thus, an average population of 20 plants per pot (481 plants $\mathrm{m}^{-2}$ ) was used.

The second and third experiments were conducted from January to March, 2013, in replacement series, with three replications, combining soybean crops and susceptible or resistant (LLRG) goosegrass biotypes, with 20 plants per pot. The seeds of both species were sown in 128-cell trays filled with a commercial substrate $\left(\right.$ GerminaPlant $\left.^{\mathbb{R}}\right)$ and then the seedlings of both species were transplanted, establishing their populations in the pots. The ratio of soybean to susceptible (Experiment 2) or resistant (LLRG) (Experiment 3) goosegrass plants were 100:0, 75:25, 50:50, 25:75 and 0:100.

The leaf area (LA) $\left(\mathrm{cm}^{2}\right.$ plant $\left.{ }^{-1}\right)$, plant height $\left(\mathrm{cm} \mathrm{plant}^{-1}\right)$ and SDW (g plant $\left.{ }^{-1}\right)$ were evaluated at 40 DAE of the soybean crop and weed. The LA was measured with a leaf area measurer (model LI $3100 \mathrm{C}$ ), the plant height was measuring from the 
plant base to the end of the last fully expanded leaf, and the SDW was quantified as previously described.

The variables were analyzed through the method of graphical analysis of the relative productivity, which consists in development of diagrams based on the relative (RP) and total relative (TRP) productivity. When the result of RP tends to a straight line, the species abilities are equivalent; a concave line indicates growth loss for one or both species; and a convex line indicates an advantageous growth for one or both species. When the TRP is equal to the unity (1) (straight line), the species are competing for the same resources; a TRP higher than 1 (convex line) indicates absence of competition; and a TRP lower than 1 (concave) indicates growth loss for both species (COUSENS, 1991).

In addition to the analysis of RP and TRP, the results were subjected to analysis of variance, and when the means were significant $(\mathrm{p}<0.05)$ by the $\mathrm{F}$ test, they were compared by the Dunnett test $(p<0.05)$, considering the species sole cultivation as control.

The relative competitiveness index (RCI) and coefficients of relative clustering (K) and competitiveness (C) were calculated. The RCI compares the growth of the species $\mathrm{X}$ with the $\mathrm{Y} ; \mathrm{K}$ indicates the relative dominance of one species over another, with $\mathrm{K}_{\mathrm{c}}$ as the relative dominance of soybean and $\mathrm{K}_{\mathrm{w}}$ as the relative dominance of the goosegrass; and $\mathrm{C}$ indicates which species is more competitive. Thus, the joint analysis of RCI, $\mathrm{K}$ and $\mathrm{C}$ indicate the species competitiveness (COUSENS, 1991). The soybean is more competitive than the goosegrass when $\mathrm{RCI}>1, \mathrm{~K}_{\mathrm{c}}>\mathrm{K}_{\mathrm{w}}$ and $\mathrm{C}>0$; on the other hand, the goosegrass is more competitive than soy when $\mathrm{RCI}<1, \mathrm{~K}_{\mathrm{c}}<\mathrm{K}_{\mathrm{w}}$ and $\mathrm{C}<0$ (HOFFMAN; BUHLER, 2002). The T test was used to evaluate the differences between the RP, TRP, RCI, $\mathrm{K}$ and $\mathrm{C}$ values (HOFFMAN; BUHLER, 2002; ROUSH et al., 1989). The criterion to differentiate the RP and TRP curves from the hypothetical lines and evaluated the existence of differences in competitiveness was at least two of the three variables ( $\mathrm{RCI}, \mathrm{K}$ and $\mathrm{C}$ ) with significant differences by the $\mathrm{T}$ test (BIANCHI et al., 2006b).

\section{RESULTS AND DISCUSSION}

The graphic results of the combinations of soybean and goosegrass with susceptibility and lowlevel resistance to glyphosate (LLRG) showed convex lines for the crop relative productivities (RP), with values near the unit (1) or higher, for the variables leaf area (LA) and shoot dry weight (SDW) (Figures 1 and 2). Thus, the crop was more efficient in using the environmental resources compared to the weed. The plant height values were similar or below the hypothetical lines (concave lines). However, since the significance is denoted by at least two variables with significant differences (BIANCHI et al., 2006b), the crop RP differed only in SDW compared with the goosegrass biotype with LLRG (Figure 2 and Table 1). According to these results, the competition has not caused, in general, injury to the crop, regardless of the crop to weed plant ratios.

Moraes et al. (2009) found similar results of soybean RP competing with Oryza sativa. This results also confirm those found by Agostinetto et al. (2013) on soybean competing with Digitaria ciliaris, with the crop RP represented by convex lines, differentiating from the estimated lines for the variables LA and SDW. However, Silva et al. (2014) evaluated the soybean competing with susceptible and resistant Conyza bonariensis biotypes to glyphosate and found crop RP represented by concave lines, differing from the expected lines for LA, plant height and SDW, denoting productivity losses for the crop, regardless of the competing biotype. These results may be due to the competing species, since the greater the species taxonomic similarity, more similar is their requirements in the niche and greater is their competition.

The weed biotypes had lower RP values (concave lines) than the hypothetical line on the same variables, with RP differences in all variables, except the plant height of the resistant (LLRG) biotype (Figures 1 and 2 and Table 1). Thus, the competition hindered the weed development.

The total relative productivity (TRP) presented lower values than the unit (1) (concave lines) for the evaluated variables (Figures 1 and 2 ). Thus, the competition hindered the growth of both species, denoting competition for the same resources. This result confirms those found for soybean competing with resistant and susceptible Conyza bonariensis biotypes to glyphosate, by Silva et al. (2014); for soybean competing with Digitaria ciliaris biotype, by Agostinetto et al. (2013); and for soybean competing with Brachiaria plantaginea by Agostinetto et al. (2009). However, the variables evaluated differed only when the soybean was competing with the susceptible goosegrass biotype (Table 1). These results show the differences in the competitive ability of the biotypes, however, these differences cannot be attributed to the biotype susceptibility or resistance (LLRG), since they were from different places.

The soybean crop with the susceptible goosegrass biotype at lower population (25:75), and with the resistant (LLRG) biotype at equal and smaller population (50:50 and 25:75) had greater LA and SDW than as sole crop (Table 2). This results denote that the intraspecific competition is more harmful to the crop, i.e., the soybean develops better competing with a goosegrass plant than competing with another soybean plant. 

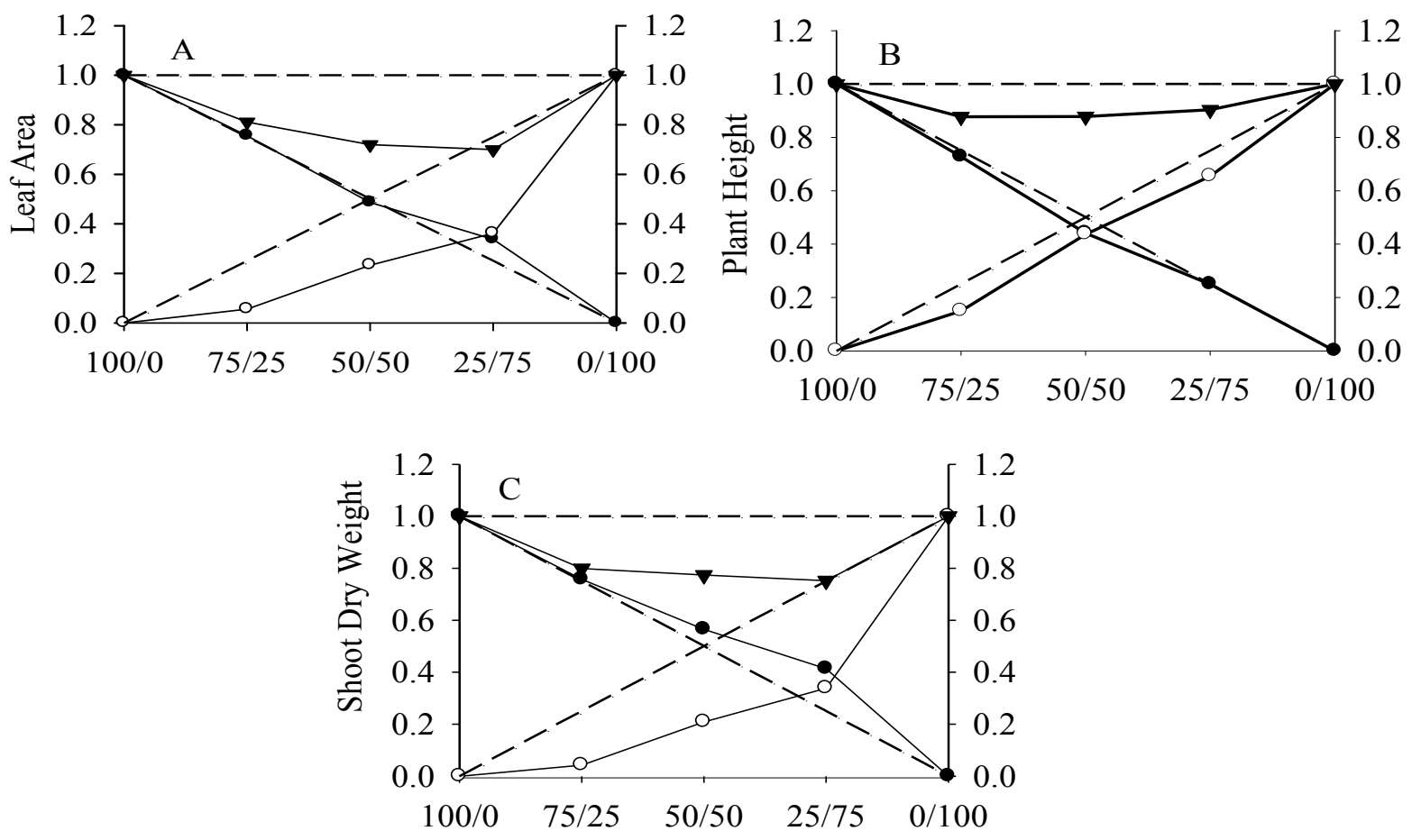

Ratio of soybean plants to susceptible goosegrass (\%)

Figure 1. Relative productivity (RP) and total relative productivity (TRP) of leaf area (A), plant height (B) and shoot dry weight (C) of soybean and susceptible goosegrass (Eleusine indica) plants to glyphosate. FAEM (UFPel), Capão do Leão, State of Rio Grande do Sul, Brazil, 2012/13. $\circ=$ RP of the susceptible goosegrass biotype (S), $\bullet=$ RP of soybean and $\boldsymbol{\nabla}=$ TRP. Dashed lines refer to the hypothetical relative productivity with no effect of one species on another.
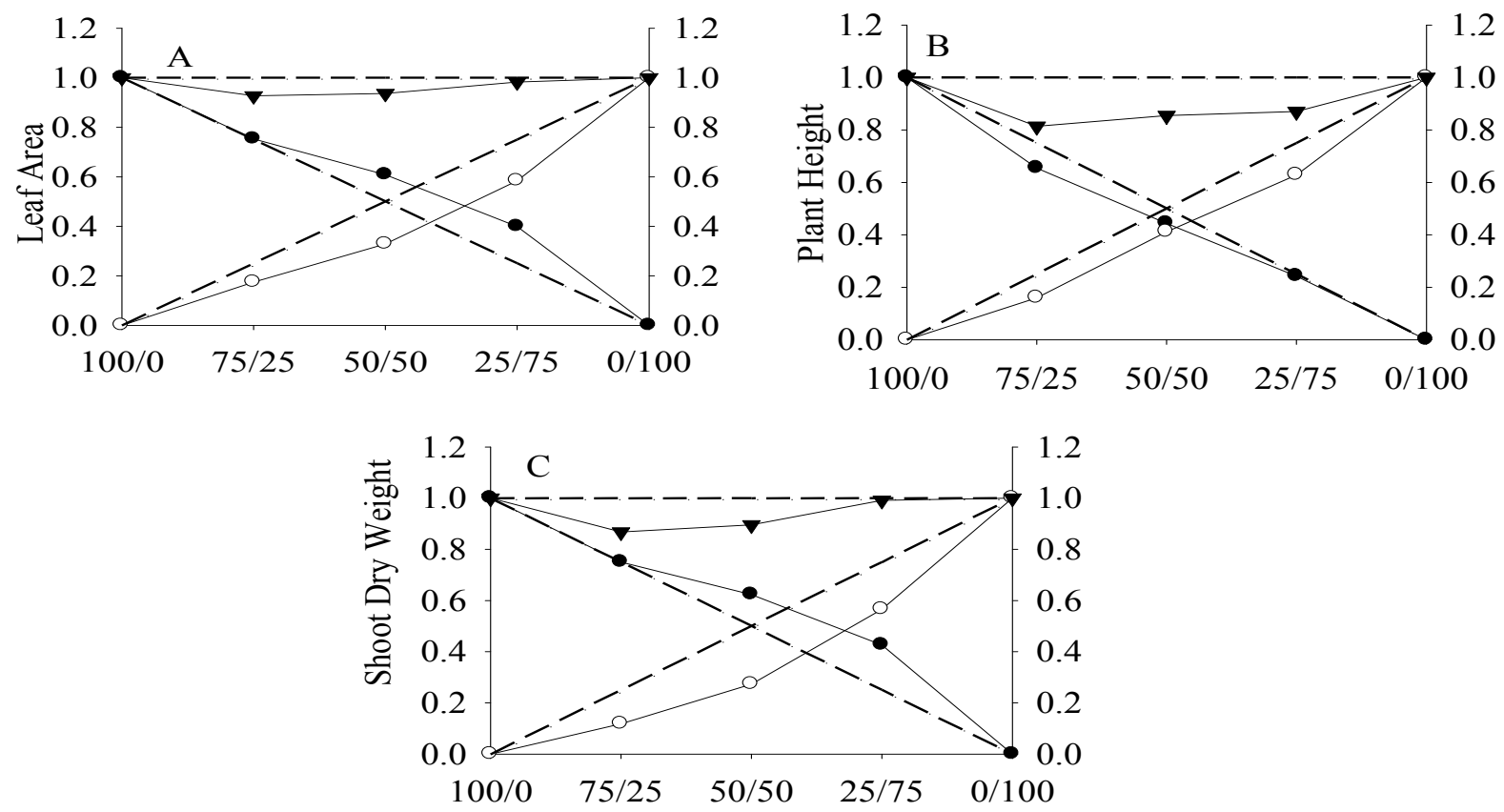

Ratio of soybean plants to resistant goosegrass (LLRG) (\%)

Figure 2. Relative productivity (RP) and total relative productivity (TRP) of leaf area (A), plant height (B) and shoot dry weight $(\mathrm{C})$ of soybean and resistant (LLRG - low-level resistance to glyphosate) goosegrass (Eleusine indica) plants. FAEM (UFPel), Capão do Leão, State of Rio Grande do Sul, Brazil, 2012/13. O = RP of the resistant (LLRG) goosegrass biotype, $\bullet=$ RP of soybean and $\boldsymbol{\nabla}=$ TRP. Dashed lines refer to the hypothetical relative productivity with no effect of one species on another. 
Table 1. Relative productivity of the leaf area, plant height and shoot dry weight and total relative productivity in different ratios of susceptible and resistant (LLRG - low-level resistance to glyphosate) goosegrass (Eleusine indica) biotypes to soybean plants (cultivar Fundacep-59). FAEM (UFPel), Capão do Leão, State of Rio Grande do Sul, Brazil, 2012/13.

\begin{tabular}{|c|c|c|c|}
\hline \multirow{3}{*}{ Biotype } & \multicolumn{3}{|c|}{ Ratio of soybean to goosegrass plants (\%) } \\
\hline & $75: 25$ & $50: 50$ & $25: 75$ \\
\hline & \multicolumn{3}{|c|}{ Leaf area } \\
\hline Soybean & $0.01( \pm 0.03)^{\mathrm{ns}}$ & $-0.01( \pm 0.01)^{\mathrm{ns}}$ & $0.09( \pm 0.01)^{*}$ \\
\hline Susceptible $E$. indica & $-0.19( \pm 0.01)^{*}$ & $-0.27( \pm 0.01)^{*}$ & $-0.39( \pm 0.04)^{*}$ \\
\hline Total & $0.81(0.03 \pm)^{*}$ & $0.72( \pm 0.01)^{*}$ & $0.70( \pm 0.03)^{*}$ \\
\hline Soybean & $0.00( \pm 0.04)^{\mathrm{ns}}$ & $0.11( \pm 0.03)^{\mathrm{ns}}$ & $0.15( \pm 0.02)^{*}$ \\
\hline Resistant (LLRG) E. indica & $-0.03( \pm 0.07)^{\mathrm{ns}}$ & $-0.17( \pm 0.03)^{*}$ & $-0.17( \pm 0.02)^{*}$ \\
\hline \multirow[t]{2}{*}{ Total } & $0.98( \pm 0.03)^{\mathrm{ns}}$ & $0.94( \pm 0.04)^{\mathrm{ns}}$ & $0.98( \pm 0.02)^{\mathrm{ns}}$ \\
\hline & \multicolumn{3}{|c|}{ Plant height } \\
\hline Soybean & $-0.02( \pm 0.01)^{\mathrm{ns}}$ & $-0.07( \pm 0.02)^{\mathrm{ns}}$ & $-0.01( \pm 0.01)^{\mathrm{ns}}$ \\
\hline Susceptible $E$. indica & $-0.10( \pm 0.01)^{*}$ & $-0.06( \pm 0.01)^{*}$ & $-0.13( \pm 0.04)^{\mathrm{ns}}$ \\
\hline Total & $0.88( \pm 0.02)^{*}$ & $0.87( \pm 0.03)^{*}$ & $0.86( \pm 0.04)^{\mathrm{ns}}$ \\
\hline Soybean & $-0.07( \pm 0.03)^{\mathrm{ns}}$ & $-0.06( \pm 0.01)^{\mathrm{ns}}$ & $-0.01( \pm 0.01)^{\mathrm{ns}}$ \\
\hline Resistant (LLRG) E. indica & $-0.05( \pm 0.02)^{\mathrm{ns}}$ & $-0.09( \pm 0.01)^{*}$ & $-0.06( \pm 0.06)^{\mathrm{ns}}$ \\
\hline \multirow[t]{2}{*}{ Total } & $0.88( \pm 0.05)^{\mathrm{ns}}$ & $0.85( \pm 0.01)^{*}$ & $0.93( \pm 0.06)^{\mathrm{ns}}$ \\
\hline & \multicolumn{3}{|c|}{ Shoot dry weight } \\
\hline Soybean & $0.01( \pm 0.05)^{\mathrm{ns}}$ & $0.06( \pm 0.03)^{\mathrm{ns}}$ & $0.16( \pm 0.01)^{*}$ \\
\hline Susceptible $E$. indica & $-0.21( \pm 0.01)^{*}$ & $-0.29( \pm 0.01)^{*}$ & $-0.41( \pm 0.04)^{*}$ \\
\hline Total & $0.80( \pm 0.04)^{*}$ & $0.77( \pm 0.03)^{*}$ & $0.75( \pm 0.03)^{*}$ \\
\hline Soybean & $0.00( \pm 0.04)^{\mathrm{ns}}$ & $0.12( \pm 0.02)^{*}$ & $0.18( \pm 0.02)^{*}$ \\
\hline Resistant (LLRG) E. indica & $-0.13( \pm 0.03)^{*}$ & $-0.23( \pm 0.04)^{*}$ & $-0.18( \pm 0.02)^{*}$ \\
\hline Total & $0.87( \pm 0.03)^{\mathrm{ns}}$ & $0.90( \pm 0.05)^{\mathrm{ns}}$ & $0.99( \pm 0.02)^{\mathrm{ns}}$ \\
\hline
\end{tabular}

${ }^{\mathrm{ns}}=$ Not significant and $*=$ significant by the $\mathrm{t}$ test $(\mathrm{p} \leq 0.05)$. Values in parentheses are the standard errors of the means.

The plant heights were, in general, similar, except the soybean in competition with the susceptible biotype at the same plant ratio. The crop may have had higher growth at smaller population due to morphophysiological differences between the species, since the plant height, biomass accumulation, canopy architecture and number and length of branches contribute to a greater competitiveness of the soybean over the weeds (BIANCHI et al., 2006a). Similar result was found for soybean competing with Oryza sativa by Moraes et al. (2009). Intraspecific competition, in general, is more important for crops, as shown by Agostinetto et al. (2009) in soybean crop with Brachiaria plantaginea, and by Agostinetto et al. (2013) in soybean with Digitaria ciliares.

The highest values of LA, plant height and SDW of the goosegrass biotypes was found in the sole cultivation, with lower productivity for the susceptible biotype in all ratios, except the plant height, which was had lower productivity at the equal or greater ratios (Table 2). The resistant (LLRG) biotype had lower plant height in all ratios and lower SDW at ratios equal or lower to the crop. On the other hand, the goosegrass averages reduced with increasing soybean ratios, denoting a predominant interspecific competition. Similar results were found by Agostinetto et al. (2013) for Digitaria ciliaris competing with soybeans, which had reduced LA and SDW averages compared to the sole weed cultivation.

According to these results, the goosegrass biotypes have better development around plants of the same species than around soybean plants. Similar results were found by Moraes et al. (2009) for Oryza sativa biotypes with soybean plants. On the other hand, Silva et al. (2014) found susceptible and resistant Conyza bonariensis biotypes to glyphosate coexisting with soybeans without affecting each other, with more important intraspecific competition for the weed. 
Table 2. Leaf area, plant height and shoot dry weight in different ratios of susceptible and resistant (LLRG - low-level resistance to glyphosate) biotypes of goosegrass (Eleusine indica) to soybean plants (cultivar Fundacep-59). FAEM (UFPel), Capão do Leão, State of Rio Grande do Sul, Brazil, 2012/13.

\begin{tabular}{|c|c|c|c|c|c|c|}
\hline \multirow{3}{*}{ Biotype } & \multicolumn{5}{|c|}{ Ratio of soybean to goosegrass plants (\%) } & \multirow[b]{2}{*}{ C.V.(\%) } \\
\hline & $100: 0$ & $75: 25$ & $50: 50$ & $25: 75$ & $0: 100$ & \\
\hline & \multicolumn{5}{|c|}{ Leaf area } & \\
\hline Soybean & 182.68 & $183.98^{\mathrm{ns}}$ & $177.72^{\mathrm{ns}}$ & $246.63^{*}$ & - & 6.27 \\
\hline Susceptible $E$. indica & - & $24.52^{*}$ & $51.54^{*}$ & $53.32^{*}$ & 110.42 & 15.95 \\
\hline Soybean & 144.76 & $145.33^{\mathrm{ns}}$ & $176.13^{*}$ & $231.00^{*}$ & - & 7.19 \\
\hline \multirow[t]{2}{*}{ Resistant (LLRG) E. indica } & - & $81.55^{\mathrm{ns}}$ & $76.85^{\mathrm{ns}}$ & $91.03^{\mathrm{ns}}$ & 116.97 & 24.41 \\
\hline & \multicolumn{5}{|c|}{ Plant height } & \\
\hline Soybean & 50.87 & $49.33^{\text {ns }}$ & $44.90^{*}$ & $50.70^{\mathrm{ns}}$ & - & 4.13 \\
\hline Susceptible $E$. indica & - & $31.4^{*}$ & $45.80^{\mathrm{ns}}$ & $45.80^{\mathrm{ns}}$ & 52.47 & 8.42 \\
\hline Soybean & 50.2 & $43.80^{\text {ns }}$ & $44.53^{\mathrm{ns}}$ & $48.67^{\mathrm{ns}}$ & - & 5.17 \\
\hline \multirow[t]{2}{*}{ Resistant (LLRG) E. indica } & - & $33.80^{*}$ & $43.6^{*}$ & $44.40 *$ & 53 & 2.53 \\
\hline & \multicolumn{5}{|c|}{ Shoot dry weight } & \\
\hline Soybean & 1.19 & $1.20^{\mathrm{ns}}$ & $1.34^{\mathrm{ns}}$ & $1.96^{*}$ & - & 8.09 \\
\hline Susceptible $E$. indica & - & $0.20^{*}$ & $0.49^{*}$ & $0.53^{*}$ & 1.17 & 17.86 \\
\hline Soybean & 0.96 & $0.96^{\mathrm{ns}}$ & $1.20^{*}$ & $1.64^{*}$ & - & 6.81 \\
\hline Resistant (LLRG) E. indica & - & $0.52^{*}$ & $0.60^{*}$ & $0.83^{\mathrm{ns}}$ & 1.10 & 19.95 \\
\hline
\end{tabular}

${ }^{n s}=$ Not significant and $*=$ significant compared with the control $(100 \%)$ by the Dunnett test $(\mathrm{p} \leq 0.05)$. C.V. $=$ coefficient of variation.

The analysis of the competitiveness indexes showed that the soybean plants had superior competitive ability to the susceptible and resistant (LLRG) goosegrass biotypes, considering the LA and SDW variables. The variable plant height presented no differences between the species (Table 3). Agostinetto et al. (2013) also found soybean plants with superior competitive ability to a Digitaria ciliaris biotype. Crops are, in general, more competitive than the weeds infesting them because the effect of the weed is not by individual competitive ability, but mainly by the total plant population (VILÀ; WILLIAMSON; LONSDALE, 2004). However, according to Silva et al. (2014), soybean crops have inferior competitive ability to resistant or susceptible Conyza bonariensis biotypes to the herbicide glyphosate.

Table 3. Competitiveness indexes of susceptible and resistant (LLRG - low-level resistance to glyphosate) biotypes of goosegrass (Eleusine indica) in soybean crops (cultivar Fundacep-59), expressed by their relative competitiveness index $(\mathrm{RCI})$ and coefficients of relative clustering $(\mathrm{K})$ and competitiveness (C). FAEM (UFPel), Capão do Leão, State of Rio Grande do Sul, Brazil, 2012/13.

\begin{tabular}{lcccc}
\hline & RCI & $\mathrm{K}_{\mathrm{c}}$ & $\mathrm{K}_{\mathrm{W}}$ & $\mathrm{C}$ \\
\cline { 2 - 4 } & \multicolumn{4}{c}{ Soybean with susceptible goosegrass } \\
\hline LA & $2.09( \pm 0.12)^{*}$ & $0.95( \pm 0.05)^{*}$ & $0.30( \pm 0.01)$ & $0.25( \pm 0.02)^{*}$ \\
Plant height & $0.98( \pm 0.02)^{\mathrm{ns}}$ & $0.76( \pm 0.05)^{\mathrm{ns}}$ & $0.78( \pm 0.03)$ & $-0.01( \pm 0.01)^{\mathrm{ns}}$ \\
SDW & $2.70( \pm 0.06)^{*}$ & $1.32( \pm 0.15)^{*}$ & $0.26( \pm 0.01)$ & $0.36( \pm 0.02)^{*}$ \\
\hline & & Soybean with resistant (LLRG) goosegrass & \\
\hline LA & $1.89( \pm 0.23)^{\mathrm{ns}}$ & $1.58( \pm 0.19)^{*}$ & $0.50( \pm 0.08)$ & $0.28( \pm 0.05)^{*}$ \\
Plant height & $1.08( \pm 0.05)^{\mathrm{ns}}$ & $0.80( \pm 0.04)^{\mathrm{ns}}$ & $0.70( \pm 0.02)$ & $0.03( \pm 0.02)^{\mathrm{ns}}$ \\
SDW & $2.38( \pm 0.35)^{\mathrm{ns}}$ & $1.67( \pm 0.14)^{*}$ & $0.38( \pm 0.07)$ & $0.35( \pm 0.04)^{*}$ \\
\hline
\end{tabular}

$\mathrm{LA}=$ Leaf area; SDW $=$ shoot dry weight; $\mathrm{K}_{\mathrm{c}}=$ coefficients of relative clustering of the soybean; $\mathrm{K}_{\mathrm{w}}=$ coefficients of relative clustering of the goosegrass; ${ }^{n s}=$ not significant and $*=$ significant by the $t$ test $(\mathrm{p} \leq 0.05)$. Values in parentheses are the standard errors of the means.

The joint interpretation of the graphical analyzes of morphological variables and competitiveness indexes showed that the soybean cultivar Fundacep-59 was more competitive than the goosegrass biotypes evaluated. The soybean crop showed similar competitive ability in both competitions, either with the susceptible or resistant (LLRG) goosegrass biotypes, which was probably due to the morphological and physiological similarities of the biotypes, since they are from the same species and explore the same ecological niches. However, the competition between these goosegrass biotypes were not evaluated, which could help to understand their different competitive ability.

The situations in which resistant weed biotypes are less competitive, cultural practices, such as increasing the number of crop plants per area and reducing their row spacing can be used to suppress the weed growth. However, since the goosegrass biotypes similarly affected soybeans, showing the same adaptability, in addition to chemical control, other control methods and monitoring of biotype populations must be adopted to control resistant (LLRG) goosegrass. 


\section{CONCLUSIONS}

The soybean crop had superior competitive ability to the goosegrass biotypes with susceptibility and low-level resistance to glyphosate (LLRG).

The soybean crop showed similar competitive ability in both competitions, either with the susceptible or resistant (LLRG) goosegrass biotypes.

The intraspecific competition was more harmful to the soybean crop, while the interspecific competition caused greater damage to the goosegrass biotypes competing with soybean.

\section{ACKNOWLEDGMENT}

The authors thank the CAPES/Brazil for granting scholarship; the Pelotas Federal University for the premises and teaching; and the Herbology Center CEHERB/FAEM/UFPel for their support to conduct these experiments.

\section{REFERENCES}

AGOSTINETTO, D. et al. Competitividade relativa da soja em convivência com papuã. Scientia Agraria, Curitiba, v. 10, n. 3, p. 185-190, 2009.

AGOSTINETTO, D. et al. Habilidade competitiva relativa de milhã em convivência com arroz irrigado e soja. Pesquisa Agropecuária Brasileira, Brasília, v. 48, n. 10, p. 1315-1322, 2013.

ALVES, G. S. et al. Períodos de interferência de plantas daninhas na cultura do girassol em Rondônia. Revista Brasileira de Engenharia Agrícola e Ambiental, Campina Grande, v. 17, n. 3, p. 275-282, 2013.

BIANCHI, M. A.; FLECK, N. G.; FEDERIZZI, L. C. Características de plantas de soja que conferem habilidade competitiva com plantas daninhas. Bragantia, Campinas, v. 65, n. 4, p. 223-632, 2006 a.

BIANCHI, M. A.; FLECK, N. G.; LAMEGO, F. P. Proporção entre plantas de soja e plantas competidoras e as relações de interferência mútua. Ciência Rural, Santa Maria, v. 36, n. 5, p. 1380-1387, 2006b.

BRASIL. Companhia Nacional de Abastecimento. Acompanhamento da Safra Brasileira de Grãos $12^{\circ}$ Levantamento - Safra 2015/16. Disponível em: http:/www.conab.gov.br/OlalaCMS/uploads/ arquivos/16_09_09_15_18_32_boletim_12_setembr o.pdf. Acesso em: $\overline{02}$ out. $\overline{201 \overline{6}}$. interpretation of competition (interference) experiments. Weed Technology, Fayetteville, v. 5, n. 3, p. 664-673, 1991.

HOFFMAN, M. L.; BUHLER, D. D. Utilizing Sorghum as a functional model of crop-weed competition. I. Establishing a competitive hierarchy. Weed Science, Athens, v. 50, n. 4, p. 466-472, 2002.

MORAES, P. V. D. et al. Competitividade relativa de soja com arroz-vermelho. Planta Daninha, Viçosa, v. 27, n. 1, p. 35-40, 2009.

RADOSEVICH, S. R.; HOLT, J.; GHERSA, C. Weed ecology: implications for management. 2. ed. New York: Willey, 1997. 589 p.

ROUSH, M. L. et al. Comparison of methods for measuring effects of density and proportion in plant competition experiments. Weed Science, Athens, v. 37, n. 2, p. 268-275, 1989.

SILVA, D. R. O. et al. Habilidade competitiva, alterações no metabolismo secundário e danos celulares de soja competindo com Conyza bonariensis resistente e suscetível a glyphosate. Planta Daninha, Viçosa, v. 32, n. 3, p. 579-589, 2014.

ULGUIM, A. R. et al. Manejo de capim pé-de-galinha em lavouras de soja transgênica resistente ao glifosato. Pesquisa Agropecuária Brasileira, Brasília, v. 48, n. 1, p. 17-24, 2013.

VARGAS, L. et al. Low level resistance of goosegrass (Eleusine indica) to glyphosate in Rio Grande do Sul-Brazil. Planta Daninha, Viçosa, v. 31, n. 3, p. 677-686, 2013.

VILA-AIUB, M. M.; NEVE, P.; POWLES, S. B. Fitness costs associated with evolved herbicide resistance alleles in plants. New Phytologist, Lancaster, v. 184, n. 4, p. 751-767, 2009.

VILÀ, M.; WILLIAMSON, M.; LONSDALE, M. Competition experiments on alien weeds with crops: lessons for measuring plant invasion impact? Biological Invasions, Knoxville, v. 6, n. 1, p. 59-69, 2004.

COUSENS, R. Aspects of the design and 